\title{
Morphometric Analysis of the Upper Premolars
}

\author{
Nenad Stošić ${ }^{1}$, Stefan Dačić ${ }^{2}$ Marina Ranđelović ${ }^{4}$, Andrijana Jovančić ${ }^{3}$, Ivana Đorđević 6 , Maja

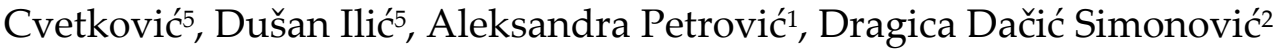 \\ ${ }^{1}$ University of Niš, Faculty of Medicine, Department of Dentistry, Niš, Serbia \\ ${ }^{2}$ University of Niš, Faculty of Medicine, Clinic of Dentistry, \\ Department of Restorative Dentistry and Endodontics, Nǐs, Serbia \\ ${ }^{3}$ University of Niš, Faculty of Medicine, Niš, Serbia \\ ${ }^{4}$ Public Health Institute Niš, Center of Microbiology, Niš, Serbia \\ ${ }^{5}$ Faculty of Medicine, University of Niš, Department of Pharmacy,Niš, Serbia \\ ${ }^{6}$ Center for Pathology and Pathological Anatomy, Clinical Center Niš, Nišs, Serbia
}

\section{SUMMARY}

Morphological and anatomical characteristics of the tooth are of great importance for clinical dentistry. These aspects of the tooth can be better conceptualized from the perspective of external and internal morphology of dental crowns and roots.

The aim of this study was to determine the average total length of the upper first and second premolars, the average length of crowns, the average length of roots and to determine the most common number of the roots and root canals of these teeth.

We used 41 first and 48 second extracted upper premolars. The length of these teeth was measured by a digital micrometer. The number of roots was determined visually, and each tooth was longitudinally dissected across the vestibular-palatal plane for determining the number of root canals.

The average total length of the upper first premolars was $22.5 \mathrm{~mm}$, the average crown length was $8.8 \mathrm{~mm}$, the mean root length was $13.7 \mathrm{~mm}$. The upper first premolars usually have two roots in $53.7 \%$ and two root canals in $82.9 \%$. The average total length of the upper second premolars was 22.5 $\mathrm{mm}$. The average crown length was $8.4 \mathrm{~mm}$ and the mean root length was $14.1 \mathrm{~mm}$. The upper second premolars usually have one root in $89.6 \%$ and one root canal in $79.2 \%$.

The determined average values of the length of these teeth and the length of their crowns and roots were similar to the values of the same population reported by other authors.

Key words: upper first premolar, upper second premolar, morphology

Corresponding author:

Nenad Stošić

e-mail: nenadstosic10@gmail.com 


\section{INTRODUCTION}

Morphological and anatomical characteristics of the teeth, as well as their variability, are of great importance for clinical dentistry. These aspects of the tooth can be better conceptualized from the perspective of external and internal morphology of dental crowns and roots.

Familiarizing with the external morphology of the tooth is important, not only because of susceptibility to dental caries and non-caries diseases of certain group of teeth, but also because of the proper treatment of the tooth, in the sense of complete functional and esthetic restoration (1). The internal morphology of the pulp chamber is shaped by the external morphology of the crown and root and, therefore, it is particularly significant for the pathology of pulp and periodontal tissues.

An endodontic treatment can not be successfully performed without the knowledge of factors such as: the number of roots, their location, shape, length and orientation, as these parameters may vary in different individuals and populations $(2,3)$.

The upper first premolar represents one of the biggest challenges for all clinicians because roots and canal systems of these teeth can vary considerably between different populations and ethnic groups $(4,5)$. The root of this tooth is very problematic, especially in the apical third. Thus, the treatment of the canal in this region has to be performed with great caution.

Frequent variation in the number of root canals, the configuration of pulp cavity and insufficient knowledge of the morphology of maxillary first and second premolars can affect the outcome of endodontic treatment. The upper premolars can have canals that are difficult for treatment because of the proximity of the maxillary sinus and variations of the apical delta (6, 7).

\section{AIM}

The aim of this study was to determine the average total length of the upper first and second premolars, the average length of crowns, the average length of roots and to determine the most common number of the roots and root canals of these teeth.

\section{MATERIAL AND METHODS}

The study sample was comprised of 89 upper jaw premolars of male and female adult patients, aged from 20 to 50 years. In total, we used 41 first upper premolars and 48 second upper premolars, extracted with an intact crown and root of the tooth and intact cement-enamel junction. Teeth were extracted either for orthodontic or prosthetic reasons. The exclusion criteria were decayed and fractured teeth and teeth with large fillings.

We applied the following procedure for the preparation of teeth: each extracted premolar from the upper jaw was carefully cleaned off residues and biological tissues, using a handpiece and steel drill, with an adequate polishing abrasive discs, a rubber band, and abrasive paste. Afterwards, we immersed the teeth into a container filled with the $10 \%$ formalin solution.

The length of these teeth was measured by a digital micrometer from the buccal cusp to the apex. The length of the crown was measured from the buccal cusp to the cement- enamel junction and the length of the root was measured from the cement-enamel border to the apex.

The number of roots was determined visually, and each tooth was longitudinally dissected across the vestibular-palatal plane for determining the number of root canals. Cutting was performed using a diamond disc mounted on a handpiece with water cooling.

\section{RESULTS}

The average total length of the upper first premolars was $22.5 \mathrm{~mm}$. The lowest length of the tooth was $20 \mathrm{~mm}$ and the maximum $24.5 \mathrm{~mm}$. Of the total number of measured upper first premolars, most of the teeth had a length of $20 \mathrm{~mm}$ and only a small proportion of teeth had a length of $24 \mathrm{~mm}$ (Table 1).

The average crown length of the upper first premolars was $8.8 \mathrm{~mm}$, and the mean root length was $13.7 \mathrm{~mm}$ (Table 1$)$. 
Table 1. The average total length of the upper first premolars and average length of their crowns and roots

\begin{tabular}{cccc}
\hline \hline Number of teeth & Length of teeth $(\mathrm{mm})$ & Length of crown $(\mathrm{mm})$ & Length of root $(\mathrm{mm})$ \\
12 & 20 & 9.5 & 10.5 \\
7 & 22.5 & 10 & 12.5 \\
9 & 23 & 8.5 & 14.5 \\
5 & 24 & 7 & 17 \\
8 & 24.5 & 8 & 16.5 \\
\hline$\sum=41$ & & & \\
\hline Average length & 22.5 & 8.8 & 13.7 \\
\hline \hline
\end{tabular}

Table 2. The average total length of the upper second premolars and average length of their crowns and roots

\begin{tabular}{cccc}
\hline \hline Number of teeth & Length of teeth $(\mathrm{mm})$ & Length of crown $(\mathrm{mm})$ & Length of root (mm) \\
11 & 18 & 9 & 9 \\
6 & 21.5 & 10 & 11.5 \\
13 & 22.5 & 8 & 14.5 \\
8 & 25 & 7 & 18 \\
10 & 26 & 8.5 & 17.5 \\
\hline$\Sigma=48$ & & & 14.1 \\
\hline Average length & 22.5 & 8.4 &
\end{tabular}

The average total length of the upper second premolars was $22.5 \mathrm{~mm}$. The lowest length of the tooth was $18 \mathrm{~mm}$ and the maximum $26 \mathrm{~mm}$. Of the total number of measured upper second premolars, most of the teeth had a length of $22.5 \mathrm{~mm}$, and only a small proportion of teeth had a length of $21.5 \mathrm{~mm}$ (Table 2).

The average crown length of the upper second premolars was $8.4 \mathrm{~mm}$ and the mean root length was $14.1 \mathrm{~mm}$ (Table 2).

Of the total number of upper first premolars, 19 (46.3\%) teeth had one root and $22(53.7 \%)$ teeth had two roots. Internal anatomy of the root of the upper first premolars showed that 6 teeth $(14.6 \%)$ had one root canal, 34 teeth $(82.9 \%)$ had two root canals, and only one tooth $(3.4 \%)$ had three root canals. The upper second premolars - 43 teeth $(89.6 \%)$ usually had one root and only 5 teeth $(10.4 \%)$ had two roots. With regard to the internal anatomy of the root of the upper second premolars, we observed the following results: 38 teeth $(79.2 \%)$ had one root canal, 9 teeth $(18.8 \%)$ had two root canals and only one tooth had three root canals (Table 3).

Table 3. The number of roots and root canals in the upper first and second premolars

\begin{tabular}{ccccc}
\hline \hline Type of teeth & No. of roots & No. of teeth \% & No. of root canals & No. of teeth $\%$ \\
\hline \multirow{3}{*}{ Upper first premolar } & 1 root & $19(46.3 \%)$ & 1 root canal & $6(14.6 \%)$ \\
& 2 roots & $22(53.7 \%)$ & 2 root canals & $34(82.9 \%)$ \\
& 3 roots & $0(0 \%)$ & 3 root canals & $1(3.4 \%)$ \\
\hline \multirow{3}{*}{ Upper second premolar } & 1 root & $43(89.6 \%)$ & 1 root canal & $38(79.2 \%)$ \\
& 2 roots & $5(10.4 \%)$ & 2 root canals & $9(18.8 \%)$ \\
& 3 roots & $0(0 \%)$ & 3 root canals & $1(2 \%)$ \\
\hline \hline
\end{tabular}




\section{DISCUSSION}

Morphological characteristics of the teeth are of substantial clinical importance. It is imperative that before each endodontic treatment dentists estimate the morphology of root canals and possible variations to avoid complications and unsuccessful outcome of endodontic treatment.

In our study, we obtained an average length of the upper first and second premolars, as well as the mean length of their crowns and length roots, which is in accordance with the values of the length of the same kind of teeth, reported by Nelson et al. (8). However, other studies with a larger sample sizes showed that there were slight discrepancies in the average lengths of these teeth from 1 to $2 \mathrm{~mm}$, compared to the results that we demonstrated (9-11).

Because of these differences in the morphology of teeth in patients of different geographic and ethnic groups (on different continents), a caution is necessary when relying on the results obtained from studies done in other populations (2).

Loh HS (2) conducted an investigation on a sample of 957 teeth and reported that the upper first premolar usually had two roots in $50.6 \%$ of cases and one root in $49.4 \%$. Similar findings were observed in studies by Carns EJ et al. (12), Vertucci FJ et al. (13) The results of our analysis support these statements. However, there are studies in which the upper first premolar usually had one root (14). Three roots, which is described as a rare phenomenon, were not observed in our study. However, some authors described that the upper first premolar may have three roots in a very limited percentage of subjects (1, 4, 14).

Numerous studies were carried out, using different methods such as radiography (15), cleaning and decalcification (3), cutting and microscopic observation and (16) computed tomography for better understanding of the morphology of the canals (17). In our study, using a method of cutting and microscopic observation, we demonstrated significant differences in the variation of the internal root morphology of the upper first and second premolars.

The upper first premolar had two canals in
$82.9 \%$ of cases. One canal was present in $14.6 \%$, and three canals in $3.4 \%$ of cases. The results of our study were in accordance with the results of Ahmad AI (18) whose study showed that the prevalence of two canals varied from $89.9 \%$ to $95 \%$, a single canal from $3.7 \%$ to $8.9 \%$, while the three canals of the upper first premolars varied from $0.2 \%-4 \%$. Similar percentages of two canals were observed in the studies of Atieh M et al. (4), Pecora J et al. (9) and Kartal N et al. (19).

The upper second premolars had more often one root $(89.6 \%)$, and two roots $(10.4 \%)$. Elkady AM et al. (20) studied the morphology of the root of the second upper premolar using CBCT (cone beam computed tomography). They found that $76.4 \%$ of teeth had one root, and the remaining $23.6 \%$ of teeth had two roots. A large distribution of one root (in $90 \%$ of cases) was also observed in the study of Pecora JD et al. (7) conducted on a much larger sample size.

The upper second premolars show many variations in the number of canals (21). In our study, it was found that the upper second premolars had one canal in $79.2 \%$ of cases, two canals in $18.8 \%$ and three canals in only $2 \%$ of cases. By comparing the results from several previous studies, the presence of teeth with two canals was significantly higher compared to the prevalence in our study $(22,23)$. Surprisingly, in our sample the percentage of the presence of one canal was reported in $79.2 \%$ of the upper second premolars, which was higher than the percentage reported by other authors, despite the fact that even in their research the percentage of one canal was more common $(6,7)$. The frequency of three canals was much lower as only one premolar had three canals $(2 \%)$, which was also observed in the study of Vertucci F et al. (24).

\section{CONCLUSION}

Anatomical and morphological variations of the upper premolar are of great importance for successful endodontic treatment. The determined average value of the length of these teeth and the length of their crowns and roots were similar to values of the same population reported by other authors. 


\section{References}

1. Nikolić M, MitićA, Gašić J, et al. Varijacije broja korenova, kanala i dužine zuba kod prvih premolara. Glasnik Antropološkog društva Srbije2014; 9: 37-41.

2. Loh HS. Root morphology of the maxillary first premolar in Singaporeans.

Aust DentJ 1998; 43: 399-402.

http://dx.doi.org/10.1111/j.1834-7819.1998.tb00199.x

3. Vertucci FJ. Root canal morphology and its relationship to endodontic procedures. Endod Top 2005; 10: 3-29.

http://dx.doi.org/10.1111/j.1601-1546.2005.00129.x

4. Atieh M. Root and canal morphology of maxillary first premolars in a saudi population. J Contemp Dent Pract 2008; 9: 46-53.

5. Rwenyonyi CM , Kutesa A, Muwazi L, Buwembo W. Root and canal morphology of maxillary first premolar teeth in a Ugandan population. Open J Stomat2011; 1: 7-11.

http://dx.doi.org/10.4236/ojst.2011.11002

6. Raj UJ,Mylswamy S. Root canal morphology of maxillary second premolars in an Indian population.J Conserv Dent 2010; 13: 148-151.

http://dx.doi.org/10.4103/0972-0707.71648

7. Pecora JD, Sousa Neto MD, Saquy PC, Woelfel JB. Root form and canal anatomy of maxillary second premolars. Braz Dent J 1992;3:81-5.

8. Nelson SJ, Ash MM. Wheeler's Dental Anatomy, Physiology and Occlusion. 9th ed. Elsevier, Spanish, 2010: 141-155.

9. Pecora JD, Saquy PC, Sousa Neto MD, Woelfel JB. Root form and canal anatomy of maxillary first premolar. Braz Dent J 1991; 2: 87-94.

10.Scheid RC, Woelfel JB. Woelfel's Dental anatomy: its relevance to dentistry. 7th ed. Lippincot Willians and Wilkins, Philadelphia, 2007: 191-7.

11. Black GV. Descriptive Anatomy of the Human Teeth. 4th ed. SS White Co, Philadelphia, 1902: $12-14$
12. Carns EJ, Skidmore AE. Configurations and deviations of root canals of maxillary first premolars. Oral Surg 1973; 36: 880-6. http://dx.doi.org/10.1016/0030-4220(73)90340-X

13. Vertucci FJ, Gegauff A. Root canal morphology of the maxillaryfirst premolar. JAm Dent Assoc 1979; 99: 194-8.

http://dx.doi.org/10.14219/jada.archive.1979.0255

14. Gupta S, Sinha DJ, Gowhar O, et al. Root and canal morphology of maxillary first premolar teeth in north Indian population using clearing technique: An in vitro study. J Conserv Dent 2015; 18: 232-6.

http://dx.doi.org/10.4103/0972-0707.157260

15. Willershausen B, Tekyatan H, Kasaj A, Marroquin BB. Roentgenographic in vitro investigation of frequency and location of curvatures in human maxillary premolars. J Endod 2006; 32: 307-11.

http://dx.doi.org/10.1016/j.joen.2005.09.011

16. Lu TY, Yang SF, Pai SF. Complicated root canal morphology of mandibular first premolar in a Chinese population using the cross section method. J Endod 2006; 32: 932-6.

http://dx.doi.org/10.1016/j.joen.2006.04.008

17. Reuben J, Velmurugan N, Kandaswamy D. The evaluation of root canal morphology of the mandibular first molar in an Indian population using spiral computed tomography scan: An in vitro study. J Endod 2008;34:212-5.

http://dx.doi.org/10.1016/j.joen.2007.11.018

18. Ahmad AI. Root and root canal morphology of Saudi Arabian permanent dentition. Saudi Endod J 2015; 5: 99-106.

http://dx.doi.org/10.4103/1658-5984.155446

19. Kartal N, Ozelik B, Cimilli H. Root canal morphology of maxillary premolars. J Endod 1998;24:417-9.

http://dx.doi.org/10.1016/S0099-2399(98)80024-1

20. Elkady AM, Allouba K. Cone beam computed tomographic analysis of root and canal morphology of maxillary premolars in Saudi subpopulation. Egyptian Dent J 2013; 59: 34193429. 
21. Calişkan MK, Pehlivan Y, Sepetçioğlu F, at al.Root canal morphology of human permanent teeth in a Turkish population. J Endod 1995; 21:200-4.

http://dx.doi.org/10.1016/S0099-2399(06)80566-2

22. Weng XL, Yu SB, Zhao SL, at al. Root canal morphology of permanent maxillary teeth in the Han nationality in Chinese Guanzhong area: a new modified root canal staining technique. J Endod 2009; 35:651-6. http://dx.doi.org/10.1016/j.joen.2009.02.010

23. Rózyło TK, Miazek M, Rózyło-Kalinowska I, Burdan F. Morphology of root canals in adult premolar teeth. Folia Morphol (Warsz) 2008; 67:280-5.

24. Vertucci F, Seelig A, Gillis R. Root canal morphology of the human maxillary second premolar. Oral Surg 1974; 38: 456-464. http://dx.doi.org/10.1016/0030-4220(74)90374-0 


\title{
Morfometrijska analiza gornjih premolara
}

\author{
Nenad Stošić1, Stefan Dačićz, Marina Ranđelović ${ }^{4}$, Andrijana Jovančić3, Ivana Đorđević6, Maja \\ Cvetković $^{5}$, Dušan Ilićs ${ }^{5}$ Aleksandra Petrović ${ }^{1}$, Dragica Dačić Simonović 2 \\ ${ }^{1}$ Univerzitet u Nišu, Medicinski fakultet, Odsek za stomatologiju, Niš, Srbija \\ ${ }^{2}$ Univerzitet $u$ Nišu, Medicinski fakultet, Klinika za stomatologiju, Departman za restorativnu \\ stomatologiju i endodonciju, Niš, Srbija \\ ${ }^{3}$ Univerzitet u Nišu, Medicinski fakultet, Niš, Srbija \\ ${ }^{4}$ Institut za javno zdravlje, Centar za mikrobiologiju, Niš, Srbija \\ ${ }^{5}$ Univerzitet u Nišu, Medicinski fakultet, Odsek za farmaciju, Niš, Srbija \\ ${ }^{6}$ Centar za patologiju i patološku anatomiju, Klinički centar Niš, Niš, Srbija
}

\section{SAŽETAK}

Morfološke i anatomske karakteristike zuba su od presudnog značaja u kliničkoj stomatologiji i mogu se posmatrati kroz spoljašnju i unutrašnju morfologiju zubne krune i korena.

Cilj istraživanja bio je da se utvrdi prosečna ukupna dužina gornjeg prvog i drugog premolara, prosečna dužina krunica, prosečna dužina korenova kao i najčešći broj korena i korenskih kanala ovih zuba.

Uzorak se sastojao od 41 ekstrahiranog prvog i 48 ekstrahiranih drugih gornjih premolara. Merenje zuba vršeno je uz pomoć digitalnog mikrometra. Broj korenova je utvrđivan vizuelno, a za utvrđivanje broja kanala korena zubi su uzdužno presecani.

Prosečna dužina gornjeg prvog premolara je bila $22.5 \mathrm{~mm}$. Prosečna dužina krunice i korena bila je $8,8 \mathrm{~mm}$, odnosno 13,7 mm. Gornji prvi premolar najčešće ima dva korena u 53,7\% uzoraka i dva kanala korena u 82,9\%. Prosečna dužina gornjeg drugog premolara je bila $22,5 \mathrm{~mm}$. Prosečna dužina krunice $i$ korena je bila 8,4 mm odnosno 14,1 mm. Gornji drugi premolar najčešće ima jedan koren u 89,6\% i jedan kanal korena u 79,2\% uzorka.

Prosečne vrednosti dužina ovih zuba, dužina njihovih krunica i korenova su slične vrednostima koje su izmerili drugi autori na našem podneblju.

Ključne reči: gornji prvi premolar, gornji drugi premolar, morfologija 